\title{
CHEMICAL DATA ON SOME ROCK-FORMING MINERALS FROM HIGH-GRADE GNEISSES, AMPHIBOLITES AND ANORTHOSITES FROM THE FISKENÆESSET AREA
}

\section{Thomas Frisch}

The area mapped by the writer is situated to the west of Fiskenæsset and lies in the boundary zone between granulite and amphibolite facies rocks (see Kalsbeek, this report). In the north a creamy- to pink-weathering gneiss, commonly containing hypersthene and biotite is the chief rock type. In the south small-folded, pale-greyweathering biotite-hornblende gneisses are predominant. Amphibolite is of common occurrence in layers, pods and agmatite. The areal extent of the anorthosite-pyribolite complex as previously outlined by reconnaissance mapping (Ghisler \& Windley, 1967) was confirmed in general but modified in detail. Additional occurrences of rocks belonging to the complex were found.

As chemical data on rock-forming minerals from West Greenland are extremely scanty some results of electron microprobe analyses of selected minerals hand-picked from samples collected in the field are presented below.

Garnet. As might be expected in a terrain largely of granulite facies grade, the garnet is typically a magnesian almandine, with up to 36 per cent of the pyrope molecule. Also notable are a spessartine-rich magnesian almandine from a granitic layer in garnet pyribolite and a grossularite from a clinopyroxene-garnet vein in anorthosite (these late veins are common in anorthosite bodies throughout the Fiskenæsset area). Analyses were made for $\mathrm{Si}, \mathrm{Ti}, \mathrm{Al}, \mathrm{Fe}, \mathrm{Mn}, \mathrm{Mg}$ and $\mathrm{Ca}$ ( $\mathrm{Cr}$ was sought but not detected) and end-member compositions have been calculated assuming that all the iron is divalent and that all the titanium is present as the titanium andradite molecule.

Garnet 1 Alm $_{60}$ Gross $_{17}$ Py $_{21}$ Spess $_{2}$

$2 \mathrm{Alm}_{65} \mathrm{Gross}_{4} \mathrm{Py}_{26} \mathrm{Spess}_{5}$

$3 \mathrm{Alm}_{55} \mathrm{Gross}_{19} \mathrm{Py}_{24}$ Spess $_{2}$

$4 \mathrm{Alm}_{58} \mathrm{Gross}_{29} \mathrm{Py}_{8}$ Spess $_{5}$

$5 \mathrm{Alm}_{61} \mathrm{Gross}_{3} \mathrm{Py}_{27} \mathrm{Spess}_{9}$
- from hypersthene gneiss

- from pegmatite in hypersthene gneiss

- from pyribolite (not associated with anorthosite)

- as above

- from granitic layer in garnetiferous pyribolite (not associated with anorthosite)

$6 \mathrm{Alm}_{49} \mathrm{Ti}-\mathrm{Andr}_{1} \mathrm{Gross}_{12} \mathrm{Py}_{36} \mathrm{Spess}_{2}$ - from layered chromite-bearing anorthosite

$7 \mathrm{Alm}_{14} \mathrm{Ti}$-Andr Gross $_{83}$ Py $_{1}$ Spess $_{1}$ - from pyroxene-garnet vein in anorthosite 
Pyroxene. The two clinopyroxenes analysed - one from a pyroxene-garnet vein in anorthosite (coexisting with garnet no. 7 above), the other from pyribolite (cf. coexisting garnet no. 3) - are salites of similar compositions, $\mathrm{Ca}_{49} \mathrm{Mg}_{31} \mathrm{Fe}_{20}$ and $\mathrm{Ca}_{46} \mathrm{Mg}_{34} \mathrm{Fe}_{20}$, respectively. Orthopyroxene from hypersthene gneiss of the Hellefiske Øer is a hypersthene of composition $\mathrm{Ca}_{1} \mathrm{Mg}_{52} \mathrm{Fe}_{47}, \mathrm{Al}_{2} \mathrm{O}_{3} 1.8 \%$.

Amphiboles from two specimens of anorthosites - one gabbroic, the other layered - were analysed. Both are magnesio-hornblendes (classification of Leake, 1968) and have the formula $\left(\mathrm{Ca}_{1.7-1.8} \mathrm{Na}_{0.3} \mathrm{~K}_{0.1-0.04}\right)\left(\mathrm{Fe}_{1.6} \mathrm{Ti}_{0.1} \mathrm{Mg}_{2.9-3.1}\right)\left(\mathrm{Si}_{6.6-6.8} \mathrm{Al}_{1.4-1.2}\right) \mathrm{O}_{23}$. (Chromium was sought but not found).

Plagioclase coexisting with the amphiboles is $\mathrm{An}_{79-82}$. (Iron and chromium were sought but not detected).

\title{
References
}

Ghisler, M. \& Windley, B. F. 1967: The chromite deposits of the Fiskenæsset region, West Greenland. Rapp. Gronlands geol. Unders. 12, 38 pp.

Leake, B. E. 1968: A catalog of analyzed calciferous and subcalciferous amphiboles together with their nomenclature and associated minerals. Spec. Pap. geol. Soc. Am. 98.

\section{FIELD INVESTIGATIONS IN THE JULIANEHÅB GRANITE ON THE NUNATAKS NORTH-WEST, NORTH AND EAST OF NARSSARSSUAQ, SOUTH GREENLAND}

\author{
Jan H. Allaart
}

\section{Pre-Gardar basement}

Before the compilation of the Narssarssuaq sheet $(1: 100000)$ could be finished, about $900 \mathrm{~km}^{2}$ of high mountainous terrain in the north-western, northern and eastern parts of the sheet area had to be mapped.

Important occurrences of supracrustal rocks have been found in three different places. One, north-west of Narssarssuaq, consists of interbanded amphibolite, semipelitic gneiss and aplitic gneiss. The two other occurrences, both in the north, consist of acid and also some intermediate porphyritic metavolcanics alternating with layers of pyroclastic rocks and aplitic gneiss.

An area exclusively consisting of aplitic gneiss has also been mapped north-west of Narssarssuaq. The original supracrustal characteristics of this gneiss are not evident, but the close similarity to the aplitic gneiss associated with the acid meta- 